Article

QUEIROZ, J.R.G. ${ }^{1 *}$ SILVA JR., A.C. ${ }^{2}$

MARTINS, D. ${ }^{2}$
* Corresponding author:

<jugobiagro@gmail.com>

Received: April 4, 2016

Approved: August 1,2016

Planta Daninha 2017; v35:e17161877

\section{Use of Prohexadione Calcium on Grass Species DEVELOPMENT}

\section{Uso do Prohexadione Cálcio no Desenvolvimento de Gramados}

ABSTRACT - This study has aimed to evaluate the effect of prohexadione-calcium as a plant growth regulator on growth and quality of Japanese lawn grass, Broadleaf carpet grass and Bermudagrass. The treatments and doses of the prohexadionecalcium tested with two three reapplications were 27.5, 55.0, 110.0, 165.0 and $165.0 \mathrm{~g}$ a.i. ha ${ }^{-1}$, and a control without application of a growth regulator. Visual injury evaluations were performed using a scale of scores and plant height and chipping dry matter were determined. We have evaluated the total thickness of the sod grass, root length and dry matter of this material at the end of the experimental period. The study was arranged in a completely randomized design with four replications. The results were submitted to analysis of variance by F-test and the averages of the treatments were compared by $t$ test at $5 \%$ probability. The prohexadione-calcium plant growth regulator was visually selective and reduced shoot growth of the three species of grass and can thus be used in the management of lawns in gardens and sports areas. As for the production of sod grass, the prohexadione-calcium can be recommended for Japanese lawn grass and Broadleaf sod grass, especially doses $165.0+165.0$ and $55.0+55.0+55.0$ respectively, because they have provided a better quality sod grass. For Bermudagrass, the effect of the treatments was harmful for the quality of sod grass and is not recommended for production purposes.

Keywords: PGR, sequential application, turfgrasses, Zoysia japonica, Axonopus compressus, Cynodon dactylon.

RESUMO - O presente trabalho teve por objetivo avaliar o uso do prohexadionecálcio como regulador vegetal sobre o desenvolvimento e a qualidade de tapetes de gramas das espécies Esmeralda, São Carlos e Bermuda. Os tratamentos e doses de prohexadione-cálcio testados, com duas e três reaplicações, foram: 27,5, 55,0, 110,0, 165,0 e 165,0 g i.a. ha ${ }^{-1}$, além de uma testemunha sem aplicação do regulador de crescimento. Foram realizadas avaliações visuais de fitotoxicidade, altura das plantas e determinação da massa seca das aparas. Ao final do estudo, avaliou-se a espessura total do tapete, o comprimento de raiz e a massa seca deste material. $O$ estudo foi instalado em um delineamento experimental inteiramente casualizado com quatro repetições. Os resultados foram submetidos à análise de variância pelo teste $F$, e as médias dos tratamentos, comparadas pelo teste t a $5 \%$ de probabilidade. O regulador vegetal prohexadione-cálcio foi visualmente seletivo e reduziu o crescimento da parte aérea das três espécies de grama, podendo ser utilizado no manejo de gramados em jardins e áreas esportivas. Quanto à produção de tapetes, o prohexadione-Ca pode ser recomendado para as gramas Esmeralda e São Carlos, com destaque para as doses de 165,0+165,0 e 55,0+55,0+55,0, respectivamente, pois proporcionaram uma melhor qualidade de tapete. Para a grama Bermuda, o efeito dos tratamentos foi prejudicial à qualidade dos tapetes, não sendo recomendado para fins de produção.

Palavras-chave: regulador de crescimento, aplicação sequencial, gramados, Zoysia japonica, Axonopus compressus, Cynodon dactylon.

1 Universidade Estadual Paulista (UNESP), Faculdade de Ciências Agronômicas, Botucatu, SP, Brasil; ${ }^{2}$ Universidade Estadual Paulista (UNESP), Faculdade de Ciências Agrárias e Veterinárias, Jaboticabal, SP, Brasil. 


\section{INTRODUCTION}

Lawns can be used in a variety of environments for different purposes, whether in residential, industrial and public areas, as well as in airports, parks, squares, slopes, slopes, road margins and in sports fields. At each site, lawns have their purpose and intrinsic characteristics, such as the grass species used, the level of maintenance and the techniques adopted (Godoy and Villas Bôas, 2003).

With respect to producing a quality sod grass, it should be tough, having high density stolons, rhizomes and roots to provide higher resistance during harvesting, handling and shipping, as well as a quick fixation in transplanting (Christians, 1998; Santos Junior, 2011). As for the maintenance of ornamental lawns, quality is related mainly to aesthetic and visual characteristics, as well as their uniformity, color, density and texture (Kuhn, 1994; Silva, 2008).

Whether for production or maintenance, the proper management of lawns enables quality improvement. In this context, the use of new techniques in the management of grasslands is highlighted, such as the use of plant growth regulators. These regulators are synthetic substances that, exogenously applied, have an action similar to that of plant hormones, such as gibberellins, for instance. These synthetic compounds that delay stretching and cell divisions in the subapical meristem are called plant growth inhibitors (Castro and Vieira, 2001).

The use of growth regulators in Brazil is still considered incipient, being used in studies with fruit plants, cereals and legumes (Marchi et al., 2013b). Among plant growth regulators available on the market, there is prohexadione-calcium, which acts to inhibit the biosynthesis of gibberellins, blocking $3 \beta$-hydroxylation of $\mathrm{GA}_{20}$ to $\mathrm{GA}_{1}$. It is a compound that presents considerable suppression in the vegetative growth in plants of apple, tomato, rice, peanut and forage turnip (Nakayama et al., 1992) and also in the management of lawn height (Miyazawa et al., 1991; Beam et al., 2002, 2003; Beam and Askew, 2005).

Applications of prohexadione-calcium have shown promise not only in the suppression of shoot growth but also in the emission of inflorescences of some grass species (Marchi et al., 2013a; Marchi et al., 2014; Rademacher, 2014; Marchi et al., 2016). However, studies on the effects of these regulators on the development of lawn roots have generated conflicting results (Maciel et al., 2011).

These products use efficiency also depends on a series of factors related to the morphoanatomical characteristics of each plant species, physicochemical characteristics of the spraying solution and also to environmental factors that interfere with plants growth. Plant species, timing of application and environmental conditions are important factors that interfere in the physiological performance of these products (Velini, 2003).

Due to the various factors that interfere in the efficiency of these products and consequently in the different results found in the literature, further studies are needed to better understand the use of plant growth regulators, either for production or maintenance, that indicate the best way to use it in management without altering the lawn quality. Therefore, the present study has aimed to evaluate the effect of prohexadione-calcium as a plant regulator on the growth and quality of the sod grass of species Japanese lawn grass (Zoysia japonica), Broadleaf carpet grass (Axonopus compressus) and Bermudagrass (Cynodon dactylon).

\section{MATERIAL AND METHODS}

Three studies were conducted, each consisting of a species of grass. The species used were: Japanese lawn grass ( $Z$. japonica), Broadleaf carpet grass (A. compressus) and Bermudagrass (Tifton) (C. dactylon).

Plastic pots with a volumetric capacity of $20.0 \mathrm{~L}$ were used, filled with soil classified as Red-Yellow Latosol (Embrapa, 2013) and fertilized based on soil analysis 40 days before transplanting. At the time of transplanting the grass to the pots, which occurred on November 20,2013 , the sod grass was cut with the help of a $15 \times 15 \mathrm{~cm}$ machete so that the edge of the pots would not limit the sod grass lateral growth and the pots were kept in the sun with water replenishment when necessary. 
The study was conducted in a completely randomized experimental design with four replications and each pot represented a plot. Doses of prohexadione-calcium (prohexadione-Ca), tested in two or three sequential applications, were: 27.5, 55.0, 110.0 and $165.0 \mathrm{~g}$ a.i. ha ${ }^{-1}$, besides a control without application of the growth regulator. Spraying was done in the morning, under average temperature conditions of $26{ }^{\circ} \mathrm{C}$, wet soil, relative air humidity around $80 \%$ and wind speed ranging between 3.5 and $5 \mathrm{~km} \mathrm{~h}^{-1}$. For application, a knapsack sprayer pressurized with $\mathrm{CO}_{2}$ was used, having two Teejet XR $11002 \mathrm{VS}$ flat jet nozzles, spaced $0.50 \mathrm{~m}$, at a constant work pressure $(200 \mathrm{kPa})$, which provided a spray mix volume of $200 \mathrm{~L} \mathrm{ha}^{-1}$.

The first application took place 26 days after transplanting (Dec 16, 2013). Before the application, the lawn was mowed at $3.0 \mathrm{~cm}$ of soil height for uniformity. The second application was performed 10 days after the first application. In the treatments in which there was the third application, this one was done 10 days after the second application. The study was conducted in up to 30 days after the second application.

Visual evaluations of phytotoxicity were carried out while conducting the experiment, with mean scores assigned by three people at 10, 20 and 30 days after the second application through a score scale in which 0 corresponded to no injury and 100 to plant death, according to the methodology proposed by Brazilian Society of Weed Science [Sociedade Brasileira da Ciência das Plantas Daninhas (SBCPD)] (1995).

Also evaluated at 10, 20 and 30 days after the second application: a) Plant height, which is equivalent to the average height obtained in three distinct points in each pot, measured with a ruler graduated in millimeters; b) Collection of the chippings at a height of $3.0 \mathrm{~cm}$ from the soil to determine the dry matter. And these were placed in a forced air circulation oven at $\pm 65{ }^{\circ} \mathrm{C}$ until reaching constant mass. Harvesting the chippings was carried out with pruning shears for lawns and a portable electric vacuum cleaner with a power of $1,000 \mathrm{~W}$, with a removable dust collector where the chippings were collected.

At the end of the study period, at 30 days after the second treatment, the pots were dismantled on a 6 mesh $(0.56 \mathrm{~mm})$ sieve to avoid root loss. The sod grass, along with the root system, was washed with a high pressure washer model Home Wash Plus 120V Karcher ${ }^{\circledR}$. With a ruler graduated in millimeters, sod grass thickness was evaluated with shoots remaining after the cutting chippings (total sod grass thickness) and without shoots (roots, subsurface rhizomes), besides root length. Subsequently, this material collected, as well as the chippings, was placed in a forced air circulation oven at $\pm 65^{\circ} \mathrm{C}$ until reaching constant mass to determine the dry matter.

The results were submitted to analysis of variance by the $\mathrm{F}$ test and the means of the treatments were compared by the test at $5 \%$ probability.

\section{RESULTS AND DISCUSSION}

\section{Japanese lawn grass (Zoysia japonica)}

The prohexadione-Ca plant growth regulator was visually selective to Japanese lawn grass (Zoysia japonica). In none of the evaluations a visual symptom of injury in the plants shoots was observed. Likewise, in other similar studies, the application of this growth regulator has not provided visual symptoms of injuries to several lawns either, such as $Z$. japonica and Cynodon dactylon (Marchi et al., 2013a; Marchi et al., 2014).

Plant growth regulators such as prohexadione-Ca have as main effect the reduction in levels of $\mathrm{GA}_{1}$, which is biologically active, which causes the accumulation of its immediate precursor $\mathrm{GA}_{20}$, biologically inactive. Thus, these products are considered safer in maintaining lawn quality, unlike other regulators, which prevent the synthesis of any type of gibberellin, which can lead to injuries and greater susceptibility to environmental stresses (Rodrigues et al., 2004).

Concerning plant height, prohexadione-Ca action was observed only after 20 days after its application, when all treatments determined reductions in lawn growth, which was also recorded at 30 DAA. The highest reduction in plant height for two prohexadione-Ca applications in relation to the control was also verified at 30 DAA for the sequential application of $165+165 \mathrm{~g} \mathrm{ha}^{-1}$ (Table 1). 
Table 1 - Mean values of plant height, total sod grass thickness and sod grass thickness without shoots, according to the doses and the number of applications of prohexadione-Ca in Japanese lawn grass

\begin{tabular}{|c|c|c|c|c|c|c|}
\hline \multirow[b]{2}{*}{ Treatment } & \multirow{2}{*}{$\begin{array}{c}\text { Dose } \\
\left(\mathrm{g} \mathrm{a}^{\mathrm{a} . \mathrm{h}^{-1}} \mathrm{ha}^{-1}\right)\end{array}$} & \multicolumn{3}{|c|}{ Plants height $(\mathrm{mm})$} & \multirow{2}{*}{$\begin{array}{l}\text { Total thickness } \\
\text { of the sod grass } \\
\qquad(\mathrm{mm})\end{array}$} & \multirow{2}{*}{$\begin{array}{c}\text { Thickness of the } \\
\text { sod grass without } \\
\text { the shoots } \\
(\mathrm{mm})\end{array}$} \\
\hline & & $\begin{array}{c}10 \\
\operatorname{DAA}^{(1)}\end{array}$ & $\begin{array}{c}20 \\
\text { DAA }\end{array}$ & $\begin{array}{c}30 \\
\text { DAA }\end{array}$ & & \\
\hline Control & - & 49.8 & $59.5 \mathrm{a}$ & $63.5 \mathrm{a}$ & $67.5 \mathrm{bc}$ & $30.0 \mathrm{~b}$ \\
\hline Prohexadione-Ca & $27.5+27.5$ & 49.0 & $41.8 \mathrm{bc}$ & $50.8 \mathrm{bc}$ & $63.8 \mathrm{c}$ & $32.5 \mathrm{ab}$ \\
\hline Prohexadione-Ca & $55+55$ & 45.5 & $38.8 \mathrm{cde}$ & $44.3 \mathrm{de}$ & $71.3 \mathrm{abc}$ & $35.0 \mathrm{ab}$ \\
\hline Prohexadione-Ca & $110+110$ & 47.8 & 35.0 def & $42.0 \mathrm{ef}$ & $73.8 \mathrm{ab}$ & $35.0 \mathrm{ab}$ \\
\hline Prohexadione-Ca & $165+165$ & 47.3 & $33.3 \mathrm{ef}$ & $40.3 \mathrm{efg}$ & $78.8 \mathrm{a}$ & $37.5 \mathrm{a}$ \\
\hline Prohexadione-Ca & $27.5+27.5+27.5$ & 48.8 & $47.8 \mathrm{~b}$ & $54.8 \mathrm{~b}$ & $63.8 \mathrm{c}$ & $33.8 \mathrm{ab}$ \\
\hline Prohexadione-Ca & $55+55+55$ & 49.3 & $40.0 \mathrm{~cd}$ & $49.0 \mathrm{~cd}$ & $68.8 \mathrm{bc}$ & $31.3 \mathrm{~b}$ \\
\hline Prohexadione-Ca & $110+110+110$ & 46.8 & $31.3 \mathrm{f}$ & $38.3 \mathrm{fg}$ & $63.8 \mathrm{c}$ & $31.3 \mathrm{~b}$ \\
\hline Prohexadione-Ca & $165+165+165$ & 45.5 & $34.8 \mathrm{def}$ & $36.3 \mathrm{~g}$ & $65.0 \mathrm{c}$ & $32.5 \mathrm{ab}$ \\
\hline F tratment & & $0.64^{\mathrm{ns}}$ & $16.38 *$ & $28.21 *$ & $3.89 *$ & $1.66^{*}$ \\
\hline VC $(\%)$ & & 8.3 & 10.8 & 7.1 & 7.8 & 11.0 \\
\hline $\begin{array}{l}\text { Least significant } \\
\text { difference (LSD) }\end{array}$ & & 5.79 & 6.35 & 4.83 & 7.78 & 5.31 \\
\hline
\end{tabular}

Means followed by the same letter in the column are not statistically different from each other by the $t$ test ( $p>0.05$ ). ns: Non significant; * Significant at $5 \%$ of probability; (1) Days after the second application.

Likewise, Marchi et al. (2013a), in a study with Japanese lawn grass, have also observed that this growth regulator used in a sequential application of $200+200 \mathrm{~g}$ of ha-1 ${ }^{-1}$ was effective in reducing lawn vertical growth. On the other hand, sequential applications in smaller doses $\left(40+40 \mathrm{~g} \mathrm{ha}^{-1}\right)$ were practically ineffective in reducing vertical growth.

In a study with three wheat cultivars, Andrade (2011) has also noted that prohexadione-Ca promoted reduction of internodes length and plant height. In another study, on rice cultivation, $\mathrm{Na}$ et al. (2011) have found that prohexadione-Ca was effective in reducing plant length, suppressing rice lodging under field conditions.

As for sod grass thickness (total and without shoots) (Table 1), the sequential application of $165+165 \mathrm{~g} \mathrm{ha}^{-1}$ of prohexadione-Ca determined the highest averages, with 11.3 and $7.5 \mathrm{~mm}$ of increment in thickness, respectively. But there is no sod grass thickness standardization in the Brazilian market. Therefore, thickness is variable, this one affects sod grass fixation, and larger thicknesses can give the consumer an advantage. Thicker sod grass contains a greater amount of roots, rhizomes and stolons, which function as a reserve structure for the plant, thus promoting faster fixation or higher survival. Thicker sod grass, when compacted, presents greater mass, but also greater resistance to handling (Lima, 2009).

All treatments provided marked reductions in dry matter of chippings produced by Japanese lawn grass. However, regarding root length, plants responded indifferently to the application of this growth regulator (Table 2).

In some studies it was also recorded that sequential applications of this growth regulator provided reductions in the total amount of dry matter of chippings produced by different species of grass (Cynodon dactylon versus C. transvaaliensis, Stenotaphrum secundatum, Axonopus compressus and Zoysia japonica), which can contribute to the management of lawns, reducing the need for several cuts during the summer (Costa et al., 2009; Marchi et al., 2014, 2015). In another study, Beam and Askew (2005) have also noticed that prohexadione-Ca in doses between 140.0 and $670.0 \mathrm{~g}$ a.i. ha ${ }^{-1}$ reduced the leaf biomass of the lawn Kentucky bluegrass (Poa pratensis) and perennial rye-grass (Lolium perenne).

Sequential applications of prohexadione-Ca at 165.0+165.0 $\mathrm{g} \mathrm{ha}^{-1}, 27.5+27.5+27.5 \mathrm{~g} \mathrm{ha}^{-1}$ and $165.0+165.0+165.0 \mathrm{~g} \mathrm{ha}^{-1}$ have provided increases in the sod grass dry matter. However, the same has not occurred with the root dry matter (Table 2). This fact demonstrates that the plant 
Table 2 - Mean values of the sod grass dry matter, root dry matter, chippings dry matter, and root length due to the doses and the number of applications of prohexadione-Ca in Japanese lawn grass

\begin{tabular}{|c|c|c|c|c|c|}
\hline Treatment & $\begin{array}{c}\text { Dose } \\
\left(\mathrm{g} \mathrm{a} \text { a.i. ha }{ }^{-1}\right)\end{array}$ & $\begin{array}{l}\text { Chippings dry } \\
\text { matter } \\
\text { (g) }\end{array}$ & $\begin{array}{l}\text { Sod grass } \\
\text { dry matter } \\
(\mathrm{g})\end{array}$ & $\begin{array}{c}\text { Root dry matter } \\
\text { (g) }\end{array}$ & $\begin{array}{l}\text { Root length } \\
\quad(\mathrm{cm})\end{array}$ \\
\hline Control & - & $1.47 \mathrm{a}$ & $138.08 \mathrm{~b}$ & $2.47 \mathrm{abc}$ & $53.3 \mathrm{ab}$ \\
\hline Prohexadione-Ca & $27.5+27.5$ & $1.07 \mathrm{~b}$ & $123.18 \mathrm{~b}$ & $1.85 \mathrm{c}$ & $46.1 \mathrm{~b}$ \\
\hline Prohexadione-Ca & $55+55$ & $0.89 \mathrm{~b}$ & $138.50 \mathrm{~b}$ & $2.08 \mathrm{bc}$ & $53.0 \mathrm{ab}$ \\
\hline Prohexadione-Ca & $110+110$ & $0.96 \mathrm{~b}$ & $141.50 \mathrm{ab}$ & $2.42 \mathrm{abc}$ & $46.3 \mathrm{~b}$ \\
\hline Prohexadione-Ca & $165+165$ & $0.91 \mathrm{~b}$ & $179.50 \mathrm{a}$ & $2.59 \mathrm{abc}$ & $66.9 \mathrm{a}$ \\
\hline Prohexadione-Ca & $27.5+27.5+27.5$ & $0.88 \mathrm{~b}$ & $177.98 \mathrm{a}$ & $2.84 \mathrm{a}$ & $56.0 \mathrm{ab}$ \\
\hline Prohexadione-Ca & $55+55+55$ & $0.94 \mathrm{~b}$ & $158.00 \mathrm{ab}$ & $2.11 \mathrm{c}$ & $65.3 \mathrm{a}$ \\
\hline Prohexadione-Ca & $110+110+110$ & $0.78 \mathrm{~b}$ & $150.00 \mathrm{ab}$ & $1.84 \mathrm{c}$ & $62.1 \mathrm{ab}$ \\
\hline Prohexadione-Ca & $165+165+165$ & $0.83 \mathrm{~b}$ & $178.00 \mathrm{a}$ & $2.60 \mathrm{ab}$ & $52.0 \mathrm{ab}$ \\
\hline F treatment & & $3.19 *$ & $2.45^{*}$ & $2.69 *$ & $1.79 *$ \\
\hline $\mathrm{VC}(\%)$ & & 23.5 & 17.2 & 18.7 & 20.5 \\
\hline $\begin{array}{l}\text { Least significant } \\
\text { difference (LSD) }\end{array}$ & & 0.33 & 38.60 & 0.63 & 16.66 \\
\hline
\end{tabular}

Means followed by the same letter in the column are not statistically different from each other by the $\mathrm{t}$ test ( $\mathrm{p}>0.05)$. ${ }^{*}$ Significant at $5 \%$ probability.

regulator acted to increase rhizomes to the detriment of roots, since the production of better quality sod grass represents a potential commercial advantage for the producer.

\section{Broadleaf carpet grass (Axonopus compressus)}

The prohexadione-Ca plant regulator was visually selective to Broadleaf carpet grass. None of the visual evaluations showed any symptoms of injury in the plant shoots and zero score of phytotoxicity was assigned to all treatments tested. It is noteworthy that in some studies with type II plant growth inhibitors, as currently tested, toxicity symptoms usually occur when applied to grass (Heckman et al., 2001; McCullough et al., 2005; McCarty et al., 2011), which was not observed in this study.

Some research studies have shown that when initial phytotoxicity symptoms by some growth regulators occur, they rapidly dissipate over time without causing greater damage, as observed by Marchi et al. (2015) with the application of trinexapac-ethyl, bispyribac-sodium and prohexadione-Ca in the St. Augustine grass (Stenotaphrum secundatum).

Prohexadione-Ca in the sequential applications of $110+110,165+165,27.5+27.5+27.5$, and $165+165+165$ has provided significant reductions in plant height only in the assessment carried at 30 DAA. Likewise, Marchi et al. (2015) have observed that prohexadione-Ca in doses of 100 and $200 \mathrm{~g} \mathrm{ha}^{-1}$ was efficient in reducing growth of St. Augustine grass (Stenotaphrum secundatum), suggesting that the number of mechanical cuts in the lawn may be avoided for a period of up to 119 DAA. As for the total sod grass thickness and without shoots, it was higher when applying the triple sequential dose of $55 \mathrm{~g} \mathrm{ha}^{-1}$ of prohexadione-Ca (Table 3).

Sod grass dry matter and root length were not affected by any of the treatments tested with spraying prohexadione-Ca. For the chippings dry matter, none of the treatments differed from the control (Table 4). As for the root dry matter, it was higher when applying the dose of $55+55 \mathrm{~g} \mathrm{ha}^{-1}$ of the growth regulator. Regarding the chippings dry matter, Beam (2004) has observed a direct relationship between the increase of sequencial doses of prohexadione-Ca $(140+140$, $270+270,410+410,540+540$, and $670+670 \mathrm{~g} \mathrm{ha}^{-1}$ ) and the percentage of reduction of chipping dry matter in Zoysia japonica. The researcher also reports that the mass reductions were equivalent to the sequential application of commercially recommended doses of prohexadione-Ca for each species. 
Table 3 - Mean values of plant height, total sod grass thickness and sod grass thickness without shoots, according to the doses and the number of applications of prohexadione-Ca in Broadleaf carpet grass

\begin{tabular}{|c|c|c|c|c|c|c|}
\hline \multirow[b]{2}{*}{ Treatment } & \multirow{2}{*}{$\begin{array}{c}\text { Dose } \\
\left(\mathrm{g} \text { a.i. } \text { ha }^{-1}\right)\end{array}$} & \multicolumn{3}{|c|}{ Plants height (mm) } & \multirow{2}{*}{$\begin{array}{l}\text { Total thickness } \\
\text { of thesod grass } \\
\qquad(\mathrm{mm})\end{array}$} & \multirow{2}{*}{$\begin{array}{l}\text { Thickness of the } \\
\text { sod grass without } \\
\text { the shoots } \\
(\mathrm{mm})\end{array}$} \\
\hline & & $10 \mathrm{DAA}^{(1)}$ & 20 DAA & 30 DAA & & \\
\hline Control & - & $48.8 \mathrm{ab}$ & $65.0 \mathrm{ab}$ & $45.4 \mathrm{a}$ & $55.0 \mathrm{bc}$ & $20.0 \mathrm{~b}$ \\
\hline Prohexadione-Ca & $27.5+27.5$ & $46.3 \mathrm{ab}$ & $64.2 \mathrm{ab}$ & $41.3 \mathrm{ab}$ & $55.0 \mathrm{bc}$ & $21.3 \mathrm{ab}$ \\
\hline Prohexadione-Ca & $55+55$ & $50.6 \mathrm{ab}$ & $68.8 \mathrm{a}$ & $42.1 \mathrm{ab}$ & $55.0 \mathrm{bc}$ & $22.5 \mathrm{ab}$ \\
\hline Prohexadione-Ca & $110+110$ & $47.5 \mathrm{ab}$ & $62.1 \mathrm{ab}$ & $40.0 \mathrm{~b}$ & $51.3 \mathrm{c}$ & $22.5 \mathrm{ab}$ \\
\hline Prohexadione-Ca & $165+165$ & $46.9 \mathrm{ab}$ & $60.0 \mathrm{ab}$ & $39.6 \mathrm{~b}$ & $55.0 \mathrm{bc}$ & $20.0 \mathrm{~b}$ \\
\hline Prohexadione-Ca & $27.5+27.5+27.5$ & $44.4 \mathrm{ab}$ & $63.8 \mathrm{ab}$ & $37.5 \mathrm{bc}$ & $60.0 \mathrm{ab}$ & $21.3 \mathrm{ab}$ \\
\hline Prohexadione-Ca & $55+55+55$ & $51.6 \mathrm{a}$ & $65.8 \mathrm{ab}$ & $45.4 \mathrm{a}$ & $62.5 \mathrm{a}$ & $23.8 \mathrm{a}$ \\
\hline Prohexadione-Ca & $110+110+110$ & $42.5 \mathrm{~b}$ & $63.3 \mathrm{ab}$ & $41.7 \mathrm{ab}$ & $55.0 \mathrm{bc}$ & $21.3 \mathrm{ab}$ \\
\hline Prohexadione-Ca & $165+165+165$ & $45.6 \mathrm{ab}$ & $56.7 \mathrm{~b}$ & $33.8 \mathrm{c}$ & $58.8 \mathrm{ab}$ & $23.8 \mathrm{a}$ \\
\hline F treatment & & $1.05^{*}$ & $0.72 *$ & $4.20 *$ & $2.46^{*}$ & $1.87 *$ \\
\hline VC $(\%)$ & & 12.0 & 12.9 & 8.8 & 7.7 & 9.5 \\
\hline $\begin{array}{l}\text { Least significant } \\
\text { difference (LSD) }\end{array}$ & & 8.25 & 11.91 & 5.23 & 6.31 & 3.02 \\
\hline
\end{tabular}

Means followed by the same letter in the column are not statistically different from each other by the $t$ test $(\mathrm{p}>0.05)$. ${ }^{*}$ Significant at $5 \%$ probability; (1) Days after the second application.

Table 4 - Mean values of chippings dry matter, sod grass dry matter, root dry matter, and root length due to the doses and the number of applications of prohexadione-Ca in Broadleaf carpet grass

\begin{tabular}{|c|c|c|c|c|c|}
\hline Treatment & $\begin{array}{c}\text { Dose } \\
\left(\mathrm{g} \text { a.i. } \mathrm{ha}^{-1}\right)\end{array}$ & $\begin{array}{l}\text { Chippings dry } \\
\text { matter } \\
(\mathrm{g})\end{array}$ & $\begin{array}{c}\text { Sod grass } \\
\text { dry matter } \\
(\mathrm{g})\end{array}$ & $\begin{array}{l}\text { Root dry } \\
\text { matter } \\
(\mathrm{g})\end{array}$ & $\begin{array}{l}\text { Root length } \\
\quad(\mathrm{cm})\end{array}$ \\
\hline Control & - & $13.89 \mathrm{abc}$ & 84.50 & $4.25 \mathrm{~b}$ & 50.1 \\
\hline Prohexadione-Ca & $27.5+27.5$ & $15.20 \mathrm{ab}$ & 51.50 & $4.33 \mathrm{~b}$ & 50.0 \\
\hline Prohexadione-Ca & $55+55$ & $15.33 \mathrm{a}$ & 67.50 & $6.44 \mathrm{a}$ & 47.3 \\
\hline Prohexadione-Ca & $110+110$ & $12.47 \mathrm{abc}$ & 57.50 & $3.86 \mathrm{~b}$ & 43.4 \\
\hline Prohexadione-Ca & $165+165$ & $12.78 \mathrm{abc}$ & 67.00 & $4.00 \mathrm{~b}$ & 45.8 \\
\hline Prohexadione-Ca & $27.5+27.5+27.5$ & $14.52 \mathrm{abc}$ & 55.50 & $5.02 \mathrm{ab}$ & 48.6 \\
\hline Prohexadione-Ca & $55+55+55$ & $13.44 \mathrm{abc}$ & 52.00 & $4.37 \mathrm{~b}$ & 48.9 \\
\hline Prohexadione-Ca & $110+110+110$ & $12.09 \mathrm{bc}$ & 73.50 & $4.42 \mathrm{~b}$ & 51.0 \\
\hline Prohexadione-Ca & $165+165+165$ & $11.59 \mathrm{c}$ & 68.50 & $4.97 \mathrm{~b}$ & 48.8 \\
\hline F treatment & & $1.51^{*}$ & $0.61^{\mathrm{ns}}$ & $2.56^{*}$ & $0.52^{\mathrm{ns}}$ \\
\hline VC $(\%)$ & & 16.4 & 44.0 & 21.2 & 13.8 \\
\hline $\begin{array}{l}\text { Least significant } \\
\text { difference (LSD) }\end{array}$ & & 3.22 & 41.24 & 1.43 & 9.69 \\
\hline
\end{tabular}

Means followed by the same letter in the column are not statistically different from each other by the $t$ test ( $p>0.05$ ). ns: Non significant;

* Significant at $5 \%$ probability.

\section{Bermuda grass (Cynodon dactylon)}

The prohexadione-Ca plant regulator showed to be visually selective to Bermuda grass (Cynodon dactylon). None of the visual evaluations showed any symptoms of injury in the plant shoots and zero score of phytotoxicity was assigned to all treatments tested. However, other researchers state that initial phytotoxicity symptoms may occur when type II growth inhibitors are applied but they dissipate in a short period of time without any major damage to the lawn visual appearance (Marchi et al., 2013a, Marchi et al., 2015). 
The initial assessment carried out at 10 DAA has shown that the sequential application of prohexadione-Ca at $27.5+27.5$ and $27.5+27.5+27.5 \mathrm{~g}$ a.i. ha ${ }^{-1}$ has provided plant height statistically higher than those seen in the other treatments. However, all treatments with growth regulator behaved similarly to the control in the assessment carried out at 30 DAA (Table 5). Beam (2004) states that prohexadione-Ca suppresses the growth of common grass species but grass of more aggressive growth, such as those of the genus Cynodon, may require higher rates and/or multiple applications for efficient height management and thus reduce mowing.

Only the sequential application of the dose of $165+165+165 \mathrm{~g} \mathrm{ha}^{-1}$ of prohexadione-Ca provided a significant reduction in the sod grass thickness (total and without shoots). The other treatments behaved as the control (Table 5).

There was a dry matter reduction of chippings in all treatments with three applications besides the double application of $55 \mathrm{~g} \mathrm{ha}^{-1}$. This shows that there is an effect of the number of applications in the accumulation of dry biomass in the sod grass shoots (Table 6). Marchi et al. (2014) have observed that the period of 14 days between two applications of prohexadione-Ca at 100+100 $\mathrm{g} \mathrm{ha}^{-1}$ in Japanese lawn grass (Zoysia japonica) has resulted in shoots dry matter production reductions higher than $84 \%$ comparing with the control.

It is also possible to notice that none of the treatments tested has influenced the accumulations of dry matter in the sod grass. It should be highlighted that in the treatment with the sequential application of prohexadione-Ca the dose of $27.5+27.5+27.5 \mathrm{~g} \mathrm{ha}^{-1}$ provided the higher accumulation in terms of biomass, but statistically similar to the control (Table 6).

As for the root dry matter (Table 6), it is observed that some treatments have provided negative effects or were similar to the control. And no dose tested increased the accumulation of dry matter in the roots. In general, three applications of prohexadione-Ca were more harmful than two, which could affect sod grass quality in commercial production. It should be pointed out that, for the production of sod grass, the growth of roots and rhizomes is more important than that of the shoots in view of the greater influence on sod grass resistance, which is directly related to post-harvest management and production area yield (Christians, 1998). For root length, no negative effect of the treatments was observed in relation to the control (Table 6).

Prohexadione-calcium was visually selective to the plants of the three grass species tested: Japanese lawn grass (Zoysia japonica), broadleaf carpet grass (Axonopus compressus) and

Table 5 - Mean values of plant height, total sod grass thickness and sod grass thickness without shoots, according to the doses and the number of applications of prohexadione-Ca in Bermudagrass

\begin{tabular}{|c|c|c|c|c|c|c|}
\hline \multirow[b]{2}{*}{ Treatment } & \multirow{2}{*}{$\begin{array}{c}\text { Dose } \\
\left(\mathrm{g} \text { a.i. } \mathrm{ha}^{-1}\right)\end{array}$} & \multicolumn{3}{|c|}{ Plants height (mm) } & \multirow{2}{*}{$\begin{array}{l}\text { Total thickness } \\
\text { of the sod grass } \\
\qquad(\mathrm{mm})\end{array}$} & \multirow{2}{*}{$\begin{array}{l}\text { Thickness of the } \\
\text { sod grass without } \\
\text { the shoots } \\
(\mathrm{mm})\end{array}$} \\
\hline & & $10 \mathrm{DAA}^{(1)}$ & 20 DAA & $30 \mathrm{DAA}$ & & \\
\hline Control & - & $30.0 \mathrm{~b}$ & $65.0 \mathrm{ab}$ & $30.4 \mathrm{ab}$ & $55.0 \mathrm{ab}$ & $25.0 \mathrm{ab}$ \\
\hline Prohexadione-Ca & $27.5+27.5$ & $35.0 \mathrm{a}$ & $72.5 \mathrm{a}$ & $28.3 \mathrm{ab}$ & $53.8 \mathrm{abc}$ & $26.3 \mathrm{a}$ \\
\hline Prohexadione-Ca & $55+55$ & $30.0 \mathrm{~b}$ & $60.0 \mathrm{bc}$ & $28.8 \mathrm{ab}$ & $56.3 \mathrm{a}$ & $26.3 \mathrm{a}$ \\
\hline Prohexadione-Ca & $110+110$ & $28.8 \mathrm{~b}$ & $55.4 \mathrm{bcd}$ & $26.7 \mathrm{~b}$ & $56.3 \mathrm{a}$ & $25.0 \mathrm{ab}$ \\
\hline Prohexadione-Ca & $165+165$ & $30.0 \mathrm{~b}$ & 57.9 bcd & $29.6 \mathrm{ab}$ & $52.5 \mathrm{abc}$ & $22.5 a b c$ \\
\hline Prohexadione-Ca & $27.5+27.5+27.5$ & $35.0 \mathrm{a}$ & $61.7 \mathrm{bc}$ & $31.3 \mathrm{a}$ & $56.3 \mathrm{a}$ & $23.8 \mathrm{abc}$ \\
\hline Prohexadione-Ca & $55+55+55$ & $28.8 \mathrm{~b}$ & $55.8 \mathrm{bcd}$ & $27.5 \mathrm{ab}$ & $52.5 \mathrm{abc}$ & $22.5 a b c$ \\
\hline Prohexadione-Ca & $110+110+110$ & $26.3 \mathrm{~b}$ & $48.8 \mathrm{~d}$ & $27.9 \mathrm{ab}$ & $51.3 \mathrm{bc}$ & $21.3 \mathrm{bc}$ \\
\hline Prohexadione-Ca & $165+165+165$ & $28.8 \mathrm{~b}$ & $52.1 \mathrm{~cd}$ & $27.9 \mathrm{ab}$ & $50.0 \mathrm{c}$ & $20.0 \mathrm{c}$ \\
\hline F treatment & & $4.08^{*}$ & $3.91^{*}$ & $1.22^{*}$ & $1.91^{*}$ & $1.71^{*}$ \\
\hline $\mathrm{VC}(\%)$ & & 9.5 & 12.2 & 9.2 & 6.3 & 14.3 \\
\hline $\begin{array}{l}\text { Least significant } \\
\text { difference (LSD) }\end{array}$ & & 4.21 & 10.47 & 3.87 & 4.94 & 4.92 \\
\hline
\end{tabular}

Means followed by the same letter in the column are not statistically different from each other by the $\mathrm{t}$ test $(\mathrm{p}>0.05)$. $*$ Significant at $5 \%$ probability; (1) Days after the second application. 
Table 6 - Mean values of chippings dry matter, sod grass dry matter, root dry matter, and root length due to the doses and the number of applications of prohexadione-Ca in Bermudagrass

\begin{tabular}{|c|c|c|c|c|c|}
\hline Treatment & $\begin{array}{c}\text { Dose } \\
\left(\mathrm{g} \mathrm{a} \text { a.i. } \mathrm{ha}^{-1}\right)\end{array}$ & $\begin{array}{l}\text { Chippings dry } \\
\text { matter } \\
(\mathrm{g})\end{array}$ & $\begin{array}{l}\text { Sod grass } \\
\text { dry matter } \\
(\mathrm{g})\end{array}$ & $\begin{array}{l}\text { Root dry matter } \\
\text { (g) }\end{array}$ & $\begin{array}{l}\text { Root length } \\
\quad(\mathrm{cm})\end{array}$ \\
\hline Control & - & $16.01 \mathrm{a}$ & $81.50 \mathrm{ab}$ & $5.99 \mathrm{a}$ & $60.6 \mathrm{ab}$ \\
\hline Prohexadione-Ca & $27.5+27.5$ & $16.68 \mathrm{a}$ & $77.25 \mathrm{ab}$ & $5.13 \mathrm{abc}$ & $53.8 \mathrm{ab}$ \\
\hline Prohexadione-Ca & $55+55$ & $11.96 \mathrm{bc}$ & $78.25 \mathrm{ab}$ & $5.00 \mathrm{bc}$ & $54.4 \mathrm{ab}$ \\
\hline Prohexadione-Ca & $110+110$ & $13.06 \mathrm{abc}$ & $75.00 \mathrm{ab}$ & $5.79 \mathrm{ab}$ & $51.6 \mathrm{~b}$ \\
\hline Prohexadione-Ca & $165+165$ & $14.24 \mathrm{ab}$ & $81.00 \mathrm{ab}$ & $5.90 \mathrm{ab}$ & $66.1 \mathrm{ab}$ \\
\hline Prohexadione-Ca & $27.5+27.5+27.5$ & $10.50 \mathrm{bc}$ & $87.25 \mathrm{a}$ & $4.26 \mathrm{c}$ & $66.9 \mathrm{a}$ \\
\hline Prohexadione-Ca & $55+55+55$ & $11.05 \mathrm{bc}$ & $80.75 \mathrm{ab}$ & $4.73 \mathrm{c}$ & $54.0 \mathrm{ab}$ \\
\hline Prohexadione-Ca & $110+110+110$ & $10.31 \mathrm{c}$ & $68.50 \mathrm{~b}$ & $4.75 \mathrm{c}$ & $61.1 \mathrm{ab}$ \\
\hline Prohexadione-Ca & $165+165+165$ & $9.91 \mathrm{c}$ & $75.00 \mathrm{ab}$ & $5.04 \mathrm{abc}$ & $66.3 \mathrm{ab}$ \\
\hline $\mathrm{F}$ treatment & & $3.59 *$ & $0.87^{*}$ & $3.26^{*}$ & $1.44 *$ \\
\hline $\mathrm{VC}(\%)$ & & 21.1 & 14.4 & 12.7 & 17.2 \\
\hline $\begin{array}{l}\text { Least significant } \\
\text { difference (LSD) }\end{array}$ & & 3.89 & 16.48 & 0.96 & 14.87 \\
\hline
\end{tabular}

Means followed by the same letter in the column are not statistically different from each other by the $\mathrm{t}$ test $(\mathrm{p}>0.05)$. $*$ Significant at $5 \%$ probability.

Bermudagrass (Cynodon dactylon). In all doses testes this plant regulator was efficient in reducing growth and biomass accumulation in the shoots for Japanese lawn grass. As for Broadleaf carpet grass (Axonopus compressus (Sw.)), the reductions in growth and shoots dry matter were possible only with the applications of $165+165+165 \mathrm{~g} \mathrm{ha}^{-1}$. As for Bermudagrass, reductions may occur with triple applications with doses from $27.5 \mathrm{~g} \mathrm{ha}^{-1}$ and managing these lawns in gardens and sports areas is recommended.

Regarding the sod grass quality, for the Japanese lawn grass the thickness and the sod grass dry matter accumulation were higher with the application of prohexadione-calcium, principally in the dose of $165.0+165.0$. For Broadleaf carpet grass, the sod grass thickness was increased, highlighting the dose 55.0+55.0+55.0 and it may be recommended for Japanese lawn grass and Broadleaf carpet grass in the production of sod grass. As for Bermudagrass, the effect of the treatments was harmful for the sod grass thickness and the root dry matter and they are not recommended for this species of grass for the purpose of producing sod grass.

\section{REFERENCES}

Andrade K.M.F.C. Reguladores de crescimento aplicados em diferentes doses e épocas em cultivares de trigo [dissertação]. Ponta Grossa: Universidade Estadual de Ponta Grossa, 2011.

Beam J.B., Askew S.D. Prohexadione-calcium effects on bermudagrass, Kentucky bluegrass, perennial ryegrass, and zoysiagrass. Int Turf Soc Res J. 2005;10:286-95.

Beam J.B. Prohexadione calcium for turfgrass management and poa annua control and molecular assessment of the acetolactate synthase gene in Poa annua [tese]. Virginia Blacksburg: Faculty of the Virginia Polytechnical Institute and State University, 2004.

Beam J.B. et al. Prohexadione calcium for turfgrass and weed management. Proc. South. Weed Sci Soc. 2002;55:1-62.

Beam J.B. et al. Prohexadione-calcium for turfgrass growth regulation and annual bluegrass control. Proc Northeast Weed Sci Soc. 2003;57:1-79.

Castro P.R.E., Vieira E.L. Aplicações de reguladores vegetais na agricultura tropical. Guaíba: Agropecuária, 2001. 588 p. 
Christians N.E. Fundamental of turfgrass management. Chelsea: Arbor Press, 1998. 301 p.

Costa N.V. et al. Características morfológicas de gramas em resposta à aplicação de trinexapac-ethyl. Planta Daninha. 2009;27:113-22.

Empresa Brasileira de Pesquisa Agropecuária - Embrapa. Sistema brasileiro de classificação de solos. $3^{\text {a }}$ ed. Brasília: 2013. $353 \mathrm{p}$.

Godoy L.J.G., Villas Bôas R.L. Nutrição e adubação para gramados. Botucatu. In: Anais do Simpósio Sobre Gramados "Produção, implantação e manutenção". Botucatu: Universidade Estadual Paulista, 2003.

Heckman N.L., Horst G.L., Gaussoin R.E. Influence of trinexapac-ethyl on specific leaf weight and chlorophyll content of Poa pratensis. Inter Turfgrass Soc Res J. 2001;9:287-90.

Kuhn M.P.S. Desenvolvimento de gramados sob níveis de sombreamento [dissertação]. Porto Alegre: Universidade Federal do Rio Grande do Sul, 1994.

Lima C.P. Nutrição, produção e qualidade de tapetes de grama Bermuda e Esmeralda influenciados pela adubação nitrogenada [tese]. Botucatu: Universidade Estadual Paulista "Júlio de Mesquita Filho", 2009.

Maciel C.D.G. et al. Desenvolvimento de gramados submetidos à aplicação de retardadores de crescimento em diferentes condições de luminosidade. Planta Daninha. 2011;29:383-95.

Marchi S.R. et al. Effect of plant regulators on growth and flowering of 'Meyer' zoysiagrass. Planta Daninha. 2013a:31:695-703.

Marchi S.R. et al. Growth inhibitors in turfgrass. Planta Daninha. 2013b:31:733-47.

Marchi S.R. et al. Tifton 419' Bermudagrass (Cynodon dactylon $\times$ C. transvaaliensis) response to plant grow inhibitors. Austr $\mathbf{J}$ Crop Sci. 2014;8:1481-6.

Marchi S.R., Martins D., Costa N.V. Effects of plant regulators on the growth and flowering of Saint Augustine grass plants. Biosci J. 2015;31:785-93.

Marchi S.R. et al. Growth and flowering inhibition os Paspalum notatum with application of trinexapac-ethyl and prohexadionecalcium. Rev Bras Eng Agr Amb. 2016;20:202-8.

Mccarty L.B. et al. 'TifEagle' bermudagrass response to plant growth regulators and mowing height. Agron J. 2011;103:988-94.

Mccullough P.E., Liu H., Mccarty L.B. Response of six dwarf-type Bermudagrasses to trinexapac-ethyl. HortScience. $2005 ; 40: 460-2$

Miyazawa T. et al. Prohexadione-calcium, a new plant growth regulator for cereals and ornamental plants. Brighton Crop Prot Conf Weeds. 1991;3:967-72.

$\mathrm{Na}$ C.I. et al. Influence of prohexadione-calcium, trinexapac-ethyl and hexaconazole on lodging characteristic and gibberellin biosynthesis of rice (Oryza sativa L.). Afr J Biotechnol. 2011;10:13097-106.

Nakayama I. et al. Effects of a plant-growth regulator, prohexadione-calcium (BX-112), on the endogenous levels of gibberellins in rice. Plant Cell Physiol. 1992;33:59-62.

Rademacher W. Prohexadione-Ca and Trinexapac-Ethyl: similarities in structure but differences in biological action. Leuven, Belgium. Acta Hortic. 2014;1042:33-41.

Rodrigues J.D., Godoy L.J.G., Ono E.O. Reguladores vegetais: bases e princípios para utilização em gramados. Botucatu. In: Anais do Simpósio Sobre Gramados - "Manejo de Gramas na Produção e em Gramados Formados". Botucatu: Universidade Estadual Paulista, 2004.

Santos Junior C.E.F. Adubação nitrogenada e calagem na produção de gramas Esmeralda e Bermuda [dissertação]. Campos dos Goytacazes: Universidade Estadual do Norte Fluminense "Darcy Ribeiro", 2011.

Silva C.M.K. Morfofisiologia de gramas ornamentais e esportivas: aspectos anatômicos, morfológicos e de manejo [dissertação]. Passo Fundo: Universidade de Passo Fundo, 2008.

Sociedade Brasileira da Ciência das Plantas Daninhas - SBCPD. Procedimentos para instalação, avaliação e análise de experimentos com herbicidas. Londrina: 1995. 42 p.

Velini E.D. Utilização de fitorreguladores em gramados. Botucatu. In: Anais do Simpósio Sobre Gramados - "Produção, Implantação e Manutenção". Botucatu:Universidade Estadual Paulista, 2003. 